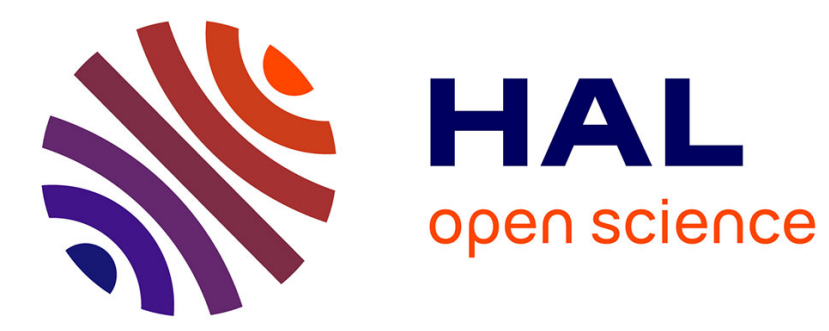

\title{
A new Myrmecophilus from Seychelles
}

\author{
Sylvain Hugel, Pat Matyot
}

\section{To cite this version:}

Sylvain Hugel, Pat Matyot. A new Myrmecophilus from Seychelles. Bulletin de la Société Entomologique de France, 2006, 111 (4), pp.469-473. 10.3406/bsef.2006.16356 . hal-03429811

\section{HAL Id: hal-03429811 \\ https://hal.science/hal-03429811}

Submitted on 15 Nov 2021

HAL is a multi-disciplinary open access archive for the deposit and dissemination of scientific research documents, whether they are published or not. The documents may come from teaching and research institutions in France or abroad, or from public or private research centers.
L'archive ouverte pluridisciplinaire HAL, est destinée au dépôt et à la diffusion de documents scientifiques de niveau recherche, publiés ou non, émanant des établissements d'enseignement et de recherche français ou étrangers, des laboratoires publics ou privés. 


\section{A new Myrmecophilus from Seychelles (Orthoptera, Grylloidea) Sylvain Hugel, Pat Matyot}

\section{Abstract}

Un nouveau Myrmecophilus des Seychelles (Orthoptera, Grylloidea). Une nouvelle espèce du genre Myrmecophilus Berthold, 1827, est décrite des Seychelles et des observations sur sa biologie sont relatées. Une clé des espèces de Myrmecophilus connues des Seychelles est donnée.

\section{Résumé}

A new species of Myrmecophilus Berthold, 1827, is described from Seychelles. Observations on its biology are reported upon. A key to the known Myrmecophilus species in Seychelles is given.

\section{Citer ce document / Cite this document :}

Hugel Sylvain, Matyot Pat. A new Myrmecophilus from Seychelles (Orthoptera, Grylloidea). In: Bulletin de la Société entomologique de France, volume 111 (4), décembre 2006. pp. 469-473;

https://www.persee.fr/doc/bsef_0037-928x_2006_num_111_4_16356

\section{Ressources associées :}

Myrmecophilus

Fichier pdf généré le 04/10/2019 


\title{
A new Myrmecophilus from Seychelles (Orthoptera, Grylloidea)
}

\author{
by Sylvain HugeL* \& Pat MATYOT** \\ *UMR 7919 ULP/CNRS, 21 rue René-Descartes, F - 67084 Strasbourg cedex <hugel@neurochem.u-strasbg.fr> \\ ** Seychelles Broadcasting Corporation (SBC), P.O. Box 321, Mahé, Seychelles
}

Summary. - A new species of Myrmecuphilus Berthold, 1827, is described from Seychelles. Observations on its biology are reported upon. A key to the known Myrmecophilus species in Seychelles is given.

Résumé. - Un nouveau Myrmecophilus des Seychelles (Orthoptera, Grylloidea). Une nouvelle espèce du genre Myrmecophilus Berthold, 1827, est décrite des Seychelles et des observations sur sa biologie sont relatées. Une clé des espèces de Myrmecophilus connues des Seychelles est donnée.

Rezime. - En nouvo Myrmecophilus sorti Sesel (Orthoptera, Grylloidea). En nouvo lespes Myrmecophilus Berthold, 1827, i ganny dekrir sorti Sesel. Bann lobzervasyon lo son biolozi i ganny raporte. I annan en lakle pour idantifye bann Myrmecophilus ki'n ganny trouve Sesel.

Key words. - Seychelles, ant-loving species, endemism, Myrmecophilus, Indian Ocean.

Although both the ants (Hymenoptera, Formicidae) and crickets (Orthoptera, Grylloidea) of the Seychelles islands have been collected and studied since the end of the 19th century, starting with the collections of Charles Alluaud in 1892 (EMERY, 1894; BOLIVAR, 1895), for nearly a century no crickets of the family Myrmecophilidae were known from these islands. Even Hugh Scott of the Second Percy Sladen Trust Expedition in 1908-1909 failed to find any in spite of his meticulous collecting (SCOTT, 1932). It was only during the Soviet Zoological Expedition of 1984 that two spccics of Myrmecophilus were collected on Félicité, one of the "inner", granitic, islands (as opposed to the "outer", coralline islands): M. americanus Saussure, 1877 (one male has been collected and described as M. microscopicus Gorochov, 1994 [HUGEL, 2006]), and M. seychellensis Gorochov, 1994, known only from the females holotype and paratype. Since then there have been more observations of Myrmecophilus crickets in Seychelles but unfortunately, as is the case with the Seychellois orthopteroid fauna generally (MATYOT, 1998), no detailed taxonomical, biological or ecological studies: a specimen of an unidentified species was observed under a stone in the company of ants, also unidentified, on the island of Frégate in October 1991 (Matyot, personal observation); and specimens of at least one unidentified species were found in association with the invasive yellow crazy ant Anoplolepis gracilipes (SMITH, 1857) on Bird Island in 2000 (Hill et al., 2003). The new species described here was observed on several occasions in association with cosmotropical "tramp" species of ants inside an apartment at Anse Nord-Est on Mahé island. The specimens collected are closely related to Myrmecophilus (Myrmecophilus) gracilipes Chopard, 1924, and to M. (M.) seychellensis Gorochov, 1994. Only females of $M$. gracilipes and $M$. seychellensis are known, preventing the use of male genital characteristics to identify the specimens collected on Mahé. However, female tergite $\mathrm{X}$ and non-sexual characters clearly distinguish these specimens from both $M$. gracilipes and $M$. seychellensis females.

\section{Myrmecophilus (Myrmecophilus) mayaealberti n. sp.}

HolotyPE: $\delta$, Anse Nord-Est, Mahé, Seychelles, 24.1.2004, P. Matyot, Muséum national d'Histoire naturelle (MNHN), Paris. ALLOTYPE: $\$$, idem, 18.VII.2005, MNHN. 
PARATYPES: $\delta$, idem, 24.I.2004, MNHN; $\hat{\sigma}$, idem, 24.I.2004, coll. S. Hugel; $q$, idem, 18.VII.2005, coll. S. Hugel. All specimens are stored in alcohol.

Diagnosis. - This new species is similar to $M$. gracilipes and $M$. seychellensis by its size, the number of spines on the hindtibia and basitarsus, and the presence of processes on the last abdominal tergites. However, it differs from $M$. gracilipes by the wider hindfemora and hindtibia (fig. 1, 5), and from $M$. seychellensis by the position of the 4th (the more proximal) inner subapical spur (fig. 2,4), and the shape and size of the 4th segment of the maxillary palpi (fig. 1-3). The 2nd inner subapical spur is the shortest in the new species whereas the shortest is the 4th in both $M$. gracilipes and M. seychellensis (fig. 1,2,4). The tergite X of females is extended into a pair of rounded processes (fig. 11); these extensions are present but different in M. gracilipes (fig. 9) and M. seychellensis (fig. 10) females.

Description. - Colour : antennae, dorsal part of metanotum, dorsal part of abdomen dark brown; two dark transversally-elongated spots on the pronotum; palpi, forelegs, midlegs, hindtibia, tarsi. ventral part of abdomen, mesonotum light yellow; some specimens (better preserved?) with anterior margin of the pronotum and hindfemora (except knee) dark brown. Body: large for the genus; distinctly flattened and weakly widened. Head: eyes black and well-developed with $\approx 20$ ommatidia; maxillary palpi (fig. 3) with 4th segment not particularly widened; 5th segment twice as long as 4th segment. Pronotum: widened before the middle with sub-parallel sides after the middle. Femora I-II: 2 ventral apical spines. Femora III: slightly narrowing apically (fig. 5). Tibiae III : widened slightly just beyond the base, wider than the length of the 4th inner subapical spur, slightly narrowing to the apex; 4 inner subapical spurs (fig. 4): 2nd shortest, 1st and 3rd longest, the 4th located after the middle of the tibia (i.e. in the distal half, fig. 4); 1 outer subapical spur (fig. 5); 3 inner and 3 outer apical spurs (the 3rd apical spur the longest on both sides; the 3rd outer the longest of all, reaching the middle of the basitarsus). Basitarsus III : slightly shorter than hindtibia; 3 large dorsal spurs; 2 very long apical spurs (fig. 4, 5): outer spur slightly longer and more proximal than inner spur (fig. 4, 5). Cerci: slightly shorter than hindfemora, with distinct false segmentation.

Male. - Abdomen : posterior margin of tergites VII, VIII, IX progressively extended medially (fig. 8). Subgenital plate: wider than long with a wide notch separating rounded lobes (fig. 8). Genitalia (terminology after DESUTTER-GRANDCOLAS, 2003): pseudepiphallus in posterior view with 2 large bilobate lateral plates, the ventral lobe rounded and the dorsal forming a rounded ancora ( fig. 6-8); pseudepiphallic apodeme well formed, forming a wide inverted-U (in dorsal view, fig. 6); ectophallic invagination long and narrow, Y-shaped (in dorsal view, fig. 6); ectophallic dorsal and ventral valves slightly sclerotized; ventral lobe long and narrow, sclerotized (fig. 8).

Female. - Abdomen : posterior margin of tergites VII, VII, IX slightly extended medially (fig. 11). Tergite $\mathrm{X}$ with a pair of rounded setae-bearing extensions (fig. 11). Subgenital plate: rounded, not notched (fig.12). Ovipositor: sclerified part of dorsal valves dorsally with denticle near apex (fig. 12).

Etymology. - The specific epithet mayaealberti honours the parents of the junior author, May Albert and Albert Mathiot, who have constantly provided encouragement and logistical support during the study of the orthopteroid fauna of Seychelles.

Fig. 1 to 12. - Myrmecophilus. - 1-2, Inner side of the right hindleg (above) and maxillary palpi, side view (below). - 1, M. gracilipes Chopard, 1924 (after CHOPARD, 1924). - 2, M. seychellensis Gorochov, 1994 (after GOROCHOV, 1994). - 3-8, Myrmecophilus mayaealberti n. sp., $\delta$ holotype. - 3, Maxillary palpi, side view. -4 , Inner side of right hind tibia and tarsus (the arrow indicates the middle of the tibia; the outer spurs are not shown). -5 , Outer side of the right hindleg (inner spurs are not shown). $-6-8$, Genitalia $\delta(6$, dorsal view, pseudepiphallus in bold; 7 , left side view of pseudepiphallus; 8, posterior view of the abdomen) (A: pseudepiphallic ancora; EI : ectophallic invagination; PA: pseudepiphallic apodeme; MVL : median ventral lobe; PC : paraproct; V : ectophallic valves; VL : ventral lobe of pseudepiphallus). 9-11, Last abdominal tergites of females (dorsal view) - 9, M. gracilipes Chopard, 1924 (after CHOPARD, 1924). - 10, M. seychellensis Gorochov, 1994 (after GoROCHOv, 1994). - 11, M. mayaealberti n. sp., 9 allotype. - 12, M. mayaealberti n. sp., $\&$ allotype, ovipositor in left side (above) and ventral views (below). Scale bar $=0.2 \mathrm{~mm}$ (fig. 3, 6-8) $=0.5 \mathrm{~mm}$ (fig. 4-5, 11-12). 
Bulletin de la Société entomologique de France, 111 (4), 2006 : 469-473

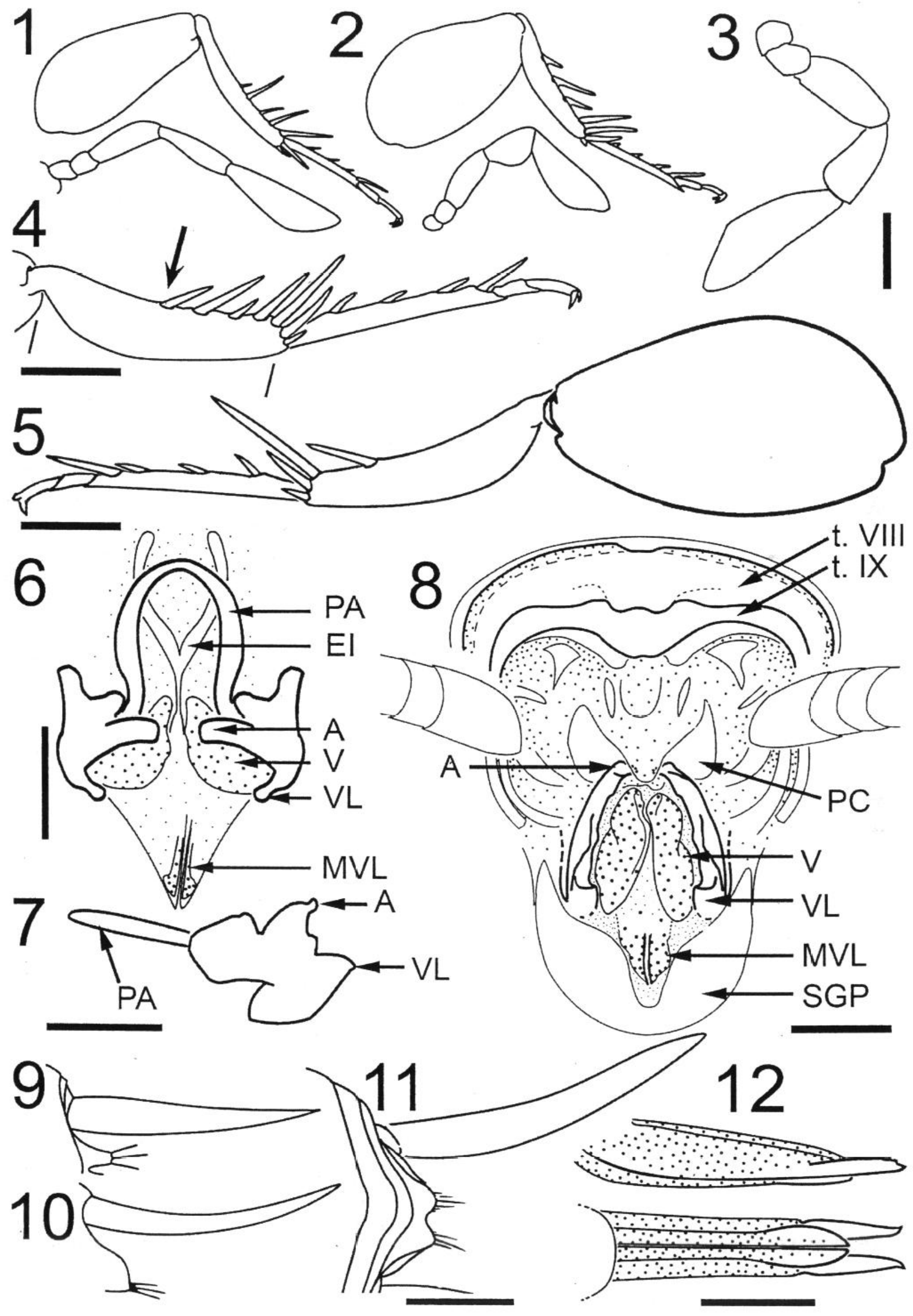


Table I. - Measurements of Myrmecophilus mayaealberti $\mathrm{n}$. sp.

\begin{tabular}{|c|c|c|c|c|c|c|c|}
\cline { 4 - 7 } \multicolumn{1}{c|}{} & \multirow{2}{*}{ Body } & \multirow{2}{*}{ Antenna } & \multicolumn{2}{c|}{ Pronotum } & \multicolumn{2}{c|}{ Hindfemora } & \multirow{2}{*}{ Ovipositor } \\
\cline { 4 - 8 } & & & Length & Width & Length & Width & \\
\hline $\begin{array}{c}\text { O Holotype } \\
\text { range }(\mathrm{n}=3)\end{array}$ & 3.6 & 7.5 & 1.1 & 1.6 & 1.9 & 1.1 & - \\
\hline O Allotype & $2.5^{*}-3.6$ & $7-8$ & $1.0-1.1$ & $1.6-1.7$ & $1.8-1.9$ & $1.1-1.2$ & 1.4 \\
O Paratype & 3.3 & $>3.5$ & 0.9 & 1.7 & 1.8 & 1.1 & 1.5 \\
\hline
\end{tabular}

All values are in $\mathrm{mm}$; ${ }^{*}$ the specimen is shrunken.

Discussion. - The posterior extensions of the last abdominal sclerites of the male constitute a unique feature of this new species compared to all other Myrmecophilus with known males (males of other species, e.g. M. thermitophilus Maran, 1959, and M. chocolatinus Gorochov, 1994, have a rounded protrusion restricted to the 10th tergite). The setae-bearing pair of extensions of the tergite $\mathrm{X}$ of $M$. mayaealberti $\mathrm{n}$. sp. females is also present but clearly different in females of $M$. gracilipes and $M$. seychellensis (fig. 9-11). In these three species, the shape of the extension and perhaps its chaetotaxy are useful taxonomic characters.

In spite of the clearly valuable diagnostic significance of male genitalia, few authors are using this to characterize Myrmecophilus species. The shapes of the lateral plates and apodeme of the pseudepiphallus (sensu DESUTTER-GRANDCOLAS, 2003) seem to be the most relevant male genital characters for diagnosis at the species level. These pseudepiphallic characters have been described and/or illustrated, at least partially, by some authors (DESUTTER-GRANDCOLAS, 1997 ; GOROCHOV, 1980, 1992, 1994; INGRISCH, 1995). However, other male genital structures could have a diagnostic significance, but such data (e.g. concerning the ectophallus) are unfortunately usually lacking.

Biology. - Males of M. mayaealberti $\mathrm{n}$. sp. were observed on several occasions indoors in the company of two cosmotropical "tramp" ant species, the "yellow crazy ant", Anoplolepis gracilipes (Smith, 1857), and the "black crazy ant", Paratrechina longicornis (Latreille, 1802). In each case they were accompanying workers carrying brood during what appeared to be "evacuations" of nests in crevices in the kitchen and bathroom walls of a bedsitter flat at Anse Nord-Est on Mahé island, or under linoleum sheets on the floor inside the flat. The crickets even crept up vertical surfaces of walls as they moved along with the ants along trails leading away from the nests. It was not possible to observe any of these "evacuations" for prolonged periods, but up to two males of $M$. mayaealberti $n$. sp. were seen within the first five minutes of any observation. Individual females were observed on at least four occasions wandering on the floor or on vertical surfaces of walls, unaccompanied by ants but within less than a metre of crevices occupied by nesting $A$. gracilipes. All sightings of $M$. mayaealberti n. sp. were made between $21: 00$ and 23:30 hrs. No crickets were observed on ordinary foraging trails of either ant species, although in North America M. manni Schimmer, 1911, is known to be "active on foraging trails", this involving "both sexes and all nymphal instars" (HENDERSON \& AKRE, 1986); but more detailed research needs to be conducted to confirm that $M$. mayaealberti $\mathrm{n}$. sp. does not also behave in this manner. In the case of M. manni it is known that "crickets relocate with the (ant) colony by using the trails (established by the relocating ants)" (HENDERSON \& AKRE, 1986). The sightings at Anse Nord-Est, as well as the previously reported occurrence on Bird Island of Myrmecophilus sp. in the company of the ant $A$. gracilipes (HILL et al., 2003), confirm the association between some Myrmecophilus species and invasive ants (HUGEL \& BLARD, 2005). At this stage, we can only speculate as to whether M. mayaealberti $\mathrm{n}$. sp. is an exotic species that has been introduced to Seychelles with invasive alien ants, or whether it is a native (possibly endemic) species that has been able to adapt to alien hosts. 


\section{Key to Myrmecophilus of Seychelles}

1. Basitarsus III with less than 3 dorsal spines (in addition to the apical two)

M. americanus Saussure, 1877

- Basitarsus III with 3 dorsal spines (in addition to the apical two)

2. 4th (the more proximal) inner subapical spur inserted distinctly before the middle of hindtibia (fig. 2), 4 th segment of maxillary palpi distinctly widened (fig. 2) M. seychellensis Gorochov, 1994

- 4th (the more proximal) inner subapical spur inserted at the middle of hindtibia (Fig. 4), 4th segment of maxillary palpi not particularly widened (fig. 3 )

M. mayaealberti n. sp.

ACKNOWLEDGEMENTS. - We thank Laure Desutter-Grandcolas for her constructive comments on the manuscript.

\section{LITERATURE CITED}

Bolivar I., 1895. - Mission scientifique de M. Ch. Alluaud aux îles Séchelles: orthoptères. Annales de la Société entomologique de France, 64 : 369-386.

CHOPARD L., 1924. - The fauna of an island in the Chilka Lake. The Dermaptera and Orthoptera of Barkuda Island. Records of the Indian Museum, 26: 165-191.

DESUTTER-GRANDCOLAS L., 1997. - First record of ant-loving crickets (Orthoptera, Myrmecophilidae, Myrmecophilinae) in New Caledonia. Journal of the Australian Entomological Society, 36: 159-163. 2003. - Phylogeny and the evolution of acoustic communication in extant Ensifera (Insecta, Orthoptera). Zoologica Scripta, 32 : 525-561.

EMERY C., 1894. - Mission scientifique de M. Ch. Alluaud aux îles Séchelles: formicides. Annales de la Société entomologique de France. 63 : 67-72.

GOROCHOV A.V., 1980. - Morphological peculiarities of crickets of the genera Myrmecophilus Berth. and Eremogryllodes Chop. and systematic position of the tribe Bothriophylacini (Orthoptera, Gryllidae). 1. Entomological Review (= English translation of Entomologicheskoye Obozreniye), 59 : 36-52. 1992. - Four new grylloid species (Orthoptera, Grylloidea) from Vietnam. P. 28-33, in: Medvedev L.N. [ed.], Sistematika i ekologiya nasekomykh Vietnama, 1-264; Moscow (Nauka).

- 1994. - Contribution to the knowledge of the Grylloidea (Orthoptera) of the Seychelles. Entomological Review (= English translation of Entomologicheskoye Obozreniye), 73 (9): 103-110.

HENDERSON G. \& AKRE R.D., 1986. - Biology of the myrmecophilous cricket, Myrmecophila manni (Orthoptera: Gryllidae). Journal of the Kansas Entomological Society, 59 (3): 454-467.

HILl M., HOLM K., Vel T., SHAH N.J. \& MATYOT P., 2003. - Impact of the introduced yellow crazy ant Anoplolepis gracilipes on Bird Island, Seychelles. Biodiversity and Conservation, 12: 1969-1984.

Hugel S., 2006. - Note synonymique sur Myrmecophilus americanus Saussure, 1877, et présence de M. quadrispina Perkins, 1899, à l'île Maurice (Orth., Myrmecophilinae). Bulletin de la Société entomologique de France, 111 (4): 448.

Hugel S. \& BLARD F., 2005. - Présence de Grillons du genre Myrmecophilus à l'île de la Réunion (Orthoptera, Myrmecophilinae). Bulletin de la Société entomologique de France, 110 (4/5): 387-389.

INGRISCH S., 1995. - Eine neue Ameisengrille aus Borneo. Entomologische Zeitschrift, 105 : 421-440.

MATYOT P., 1998. - The orthopteroids of the Seychelles: a threatened island fauna. Journal of Insect Conservation, 2 : 235-246.

SCOTT H., 1932. - Note on insects associated with ants and termites in the Seychelles Islands. Entomologist's Monthly Magazine, 68 : 169-172. 